\title{
Hypolipidemic Activities of a Series of Pyrazoles of Curcumin
}

\author{
Honnalagere Ramesh Puneeth, Angatahally Chandrashekariah Sharada* \\ Department of Biochemistry, Yuvaraja's College, University of Mysore Mysore, Karnataka, India-570005.
}

\begin{abstract}
A series of curcumin pyrazole derivatives (3a-3e) were investigated for in-vitro hypolipidemic activity. The compounds were screened for the inhibition studies of the enzymes such as pancreatic lipase, glucose 6 phosphate dehydrogenase and malate dehydrogenase which are actively involved in lipid metabolism. Curcumin and all the other compounds in the series showed differential enzyme inhibitory activity. Curcumin and compound $3 b$ showed prominent pancreatic lipase inhibitory activity showing $I_{50} 17.39$ and $16 \mu M$ respectively. Curcumin, compound $3 a$ and compound $3 b$ exhibited considerable malic dehydrogenase inhibitory activity and the $I C_{50}$ was found to be 23.42, 18.54 and $22.82 \mu \mathrm{M}$ respectively. Glucose 6 phosphate dehydrogenase activity was inhibited significantly by curcumin, compounds $3 a, 3 b$ and $3 e$ and $I C_{50}$ was 17.41 , $17.11,14.02$ and $18.7 \mu M$ respectively. Our results suggest that among the curcumin pyrazole derivatives (3a$3 e)$, compound $3 a$ and $3 b$ could be potential hypolipidemic agents and can be promoted for further in-vitro and in vivo investigations.
\end{abstract}

Keywords: Pancreatic lipase, enzyme inhibition, glucose 6 phosphate dehydrogenase, malate dehydrogenase, in-vitro.

\section{Introduction}

Cardiovascular disease (CVD) is a major cause of the human death in India and in many countries. Hyperlipidemia is a common threat for the accelerated atherosclerosis and cardiovascular diseases. Atherosclerosis is characterized by the formation of plaques in the walls of coronary arteries that reduces the flow of blood leading to coronary artery disease. Hypercholesterolemia contributes to the increased prevalence of coronary artery diseases [1]. Previous reports show that lowering of serum cholesterol reduces the risk of coronary artery diseases [2].

Many plants have been recognized as hypolipidemic in ayurveda, an Indian traditional medicine [3]. Curcumin is a polyphenol and is the chief active component of rhizome of the plant Curcuma longa, commonly called as turmeric. Turmeric, a traditional medicinal plant forms a vital class of adjuncts in our diet. A wide-ranging research over the decades on this polyphenol indicated that it is a persuasive therapeutic agent against various diseases [4]. Curcumin has been found to be safe even at very high doses in human clinical trials [5]. Though curcumin is used for various treatments owing to its medicinal properties, it is not an effective therapeutic molecule due to its bioavailability [6]. Numerous approaches are being sought to trounce these limitations. A variety of chemical modifications of curcumin have been studied and different analogues were synthesized to advance its pharmacological effects [7-9]. In our preceding study, we had synthesized ethanone pyridine curcumin analogues and cyclopropoxy curcumin analogues. These compounds showed anti angiogenic and in-vivo growth inhibitory effects against mouse tumor [10,11]. Further, curcumin pyrazole (3a3e) series were synthesized (Fig.1) and checked for its bioavailability [12]. The derivatives of the curcumin pyrazole series (3a-3e) were demonstrated antiproliferate, antioxidant and antidiabetic properties [12-14].

Extending the evaluation of biological activities of curcumin pyrazole series (3a-3e), in the present study, we investigated for the in-vitro hypolipidemic potential of the curcumin and its pyrazole derivatives by assessing the inhibition of the malic dehydrogenase, pancreatic lipase and glucose 6 phosphate dehydrogenase enzymes.

\subsection{Materials}

\section{Materials and Methods}

All solvents and other chemicals used in the studies were of analytical grade and purchased from SDFCL, Mumbai, India. The enzyme, NADP-malic enzyme (EC 1.1.1.40) was obtained from Sigma Aldrich, Bengaluru. The other enzymes glucose 6 phosphate dehydrogenase (EC 1.1.1.49) and pancreatic lipase (EC 3.1.1.3) were purchased from SRL, India.

\subsection{Methods}

\subsubsection{Inhibition of pancreatic lipase activity}

Hypolipidemic ability of curcumin and the pyrazole derivatives (3a-3e) were tested by assessing the pancreatic lipase inhibition assay [15]. Curcumin and its pyrazole derivatives (3a-3e) were individually 
incubated with $1 \mathrm{ml}$ of reaction mixture containing 1 Unit of lipase enzyme, $100 \mathrm{mM}$ phosphate buffer $(\mathrm{pH} 7.2)$ with triton-X-100 $(0.5 \%)$. The enzyme reaction was started by adding p-nitro phenyl butyrate $(5 \mathrm{mM}$ in acetonitrile) and monitored at $340 \mathrm{~nm}$. A control tube was maintained and the result was expressed as percent activity.

\subsubsection{Inhibition of glucose-6-phosphate dehydrogenase activity}

Glucose-6-phosphate dehydrogenase activity was measured by monitoring reduction of NADP at $340 \mathrm{~nm}$ [16]. Curcumin and its pyrazole derivatives (3a-3e) were individually incubated with $1 \mathrm{ml}$ of reaction mixture containing 0.5 Unit of enzyme, $50 \mathrm{mM}$ Tris $\mathrm{HCl}(\mathrm{pH} 7.4)$ and $0.1 \mathrm{mM}$ Glucose-6-phosphate. The enzyme reaction was started by adding $0.15 \mathrm{mM}$ NADP and monitored at $340 \mathrm{~nm}$. A control tube was maintained and the result was expressed as percent activity.

\subsubsection{Inhibition of malic dehydrogenase activity}

Malic dehydrogenase activity was measured by monitoring reduction of NADP at 340nm [17]. Curcumin and its pyrazole derivatives (3a-3e) were incubated with $1 \mathrm{ml}$ of Tris $\mathrm{HCl}(100 \mathrm{mM}, \mathrm{pH} 7.4)$ containing 0.5 Unit of Malic dehydrogenase enzyme, L-malate $(10 \mathrm{mM})$ and $\mathrm{MnCl}_{2}(2 \mathrm{mM})$. The enzyme reaction was started by adding $2 \mathrm{mM}$ NADP and monitored at $340 \mathrm{~nm}$. A control tube was maintained and the result was expressed as percent activity.

\subsection{Statistical analysis}

The data obtained were analyzed using MS-excel software. The data were expressed as mean \pm standard error of mean and all the experiments were compared with control and performed in triplicates.

\subsection{Pancreatic lipase enzyme inhibition assay}

\section{Results and Discussion}

The enzyme inhibitory efficiency of curcumin and its pyrazole derivatives (3a-3e) on pancreatic lipase at different concentrations (20-80 $\mu \mathrm{M})$ was depicted (Fig. 2).

The activity of the pancreatic lipase enzyme in the compound $3 \mathrm{~b}$ treated tubes was found to be $37.5 \pm 0.31,35 \pm 0.15$ and $27.5 \pm 0.21 \%$ at the concentrations of 20,40 and $80 \mu \mathrm{M}$ respectively. The decrease in the activity of enzyme in the curcumin treated tubes was also predominant and the activity was found to be $42.5 \pm 0.11,37.5 \pm 0.23$ and $30 \pm 0.19 \%$ at 20,40 and $80 \mu \mathrm{M}$ respectively. The activity of enzyme was found to be $35 \pm 0.16 \%$ in the tube treated with $80 \mu \mathrm{M}$ concentration of compound $3 \mathrm{e}$. The other compounds in the series showed the moderate enzyme inhibitory activity. Compounds $3 \mathrm{a}, 3 \mathrm{c}$ and $3 \mathrm{~d}$ decreased the percent activity of pancreatic lipase and the activity was found to be $47.5 \pm 0.32,52.5 \pm 0.41$ and $57.5 \pm 0.36$ respectively at $80 \mu \mathrm{M}$ concentration.

CVD is characterized by increased activity of lipases specifically, pancreatic lipases which catalyze the breakdown reactions of dietary fat into simpler fatty acids which are absorbed into the system. The enzyme activity usually increases with diabetes and CVD causing an increased absorption of fatty acids from dietary fat $[15,19]$ that increases free saturated fatty acids. When the enzyme pancreatic lipase was treated with the curcumin and its derivatives (3a-3e) the activity was decreased significantly in the tubes treated with curcumin, compound $3 \mathrm{~b}$ and $3 \mathrm{e}$ when compared to the other compounds in the series. The $\mathrm{IC}_{50}$ for curcumin and compound $3 \mathrm{~b}$ was prominent and was found to be $17.39 \mu \mathrm{M}$ and $16 \mu \mathrm{M}$ respectively (Table-1). Compound $3 \mathrm{~b}$ was found to be more effective than the curcumin. Our previous reports suggested that compound $3 \mathrm{~b}$ possess potent biological activities when compared with the others in the series. The potential biological activities of compound $3 \mathrm{~b}$ may be attributed to the structure activity relationship which needs further investigation.

\subsection{Malic dehydrogenase enzyme inhibition assay}

The malic dehydrogenase enzyme inhibitory effect of curcumin and its pyrazole derivatives (3a-3e) at different concentrations $(20-80 \mu \mathrm{M})$ was studied and the results are shown in the Fig. 3. The activity of enzyme in the curcumin treated tubes was found to be $57.3 \pm 0.24,38.2 \pm 0.21$ and $26.96 \pm 0.35 \%$ at 20,40 and $80 \mu \mathrm{M}$ respectively and in compound 3 a treated tubes, it was found to be $46.06 \pm 0.32,33.7 \pm 0.27$ and $31.46 \pm 0.25 \%$ at the concentrations of 20,40 and $80 \mu \mathrm{M}$ respectively. The activity of enzyme in the compound $3 \mathrm{~b}$ treated tubes was found to be $56.17 \pm 0.29,34.83 \pm 0.22$ and $26.96 \pm 0.19 \%$ at the concentrations of 20,40 and $80 \mu \mathrm{M}$ respectively. The other compounds in the series also showed moderate enzyme inhibitory activity. It was found to be $41.57 \pm 0.34,46.06 \pm 0.29$ and $37.07 \pm 0.18 \%$ in compounds $3 \mathrm{c}, 3 \mathrm{~d}$ and $3 \mathrm{e}$ treated tubes respectively at $80 \mu \mathrm{M}$ concentration.

NADP-malic enzyme has shown to be an important enzyme in regulating the extent of lipid accumulation in a filamentous fungus (20). The activity of the enzyme was decreased significantly in the tubes 
treated with curcumin, compound $3 \mathrm{~b}$ and $3 \mathrm{a}$ when compared to the other compounds in the series. $\mathrm{The} \mathrm{IC}_{50}$ for curcumin, compound $3 \mathrm{a}$ and $3 \mathrm{~b}$ was found to be $23.42,18.54$ and $22.82 \mu \mathrm{M}$ respectively (Table-1).

\subsection{Glucose 6 phosphate dehydrogenase enzyme inhibition assay}

The glucose 6 phosphate dehydrogensae enzyme inhibition studies was assessed at different concentrations $(20-80 \mu \mathrm{M})$ of curcumin and its pyrazole derivatives (3a-3e) and the results are given in the Fig. 4.

The activity of the glucose 6 phosphate dehydrogenase enzyme in the compound $3 \mathrm{~b}$ treated tubes was found to be $28.71 \pm 0.12,17.82 \pm 0.17$ and $14.85 \pm 0.11 \%$ at the concentrations of 20,40 and $80 \mu \mathrm{M}$ respectively. The decrease in the activity of enzyme in the curcumin treated tubes was also predominant and the activity was found to be $42.57 \pm 0.36,34.65 \pm 0.27$ and $21.78 \pm 0.22 \%$ at 20,40 and $80 \mu \mathrm{M}$ respectively. The activity of enzyme was found to be $27.72 \pm 0.23 \%$ in the tube treated with $80 \mu \mathrm{M}$ concentration of compound 3a. The other compounds in the series showed the moderate enzyme inhibitory activity. Compounds $3 \mathrm{c}, 3 \mathrm{~d}$ and $3 \mathrm{e}$ decreased the percent activity of glucose 6 phosphate dehydrogenase and the activity was found to be $35.64 \pm 0.26$ $33.66 \pm 0.31$ and $34.65 \pm 0.29$ respectively at $80 \mu \mathrm{M}$ concentration.

Glucose 6 phosphate dehydrogenase is a key enzyme for the production of NADPH that contributes for lipidogenesis [21]. The activity of the enzyme was decreased prominently in the tubes treated with curcumin, compound $3 \mathrm{~b}$ and $3 \mathrm{a}$ when compared to the other compounds in the series. The $\mathrm{IC}_{50}$ for curcumin, compound $3 \mathrm{a}$ and $3 \mathrm{~b}$ was found to be $17.41 \mu \mathrm{M}, 17.11 \mu \mathrm{M}$ and $14.02 \mu \mathrm{M}$ respectively (Table-1).

\section{Figures and Tables}<smiles>COc1cc(/C=C/C(=O)CC(=O)/C=C/c2ccc(O)c(OC)c2)ccc1O</smiles><smiles>COc1cc(/C=C/c2cc(/C=C/c3ccc(O)c(OC)c3)n(-c3ccccc3)n2)ccc1O</smiles><smiles>COc1cc(/C=C/c2cc(/C=C/c3ccc(O)c(OC)c3)n(-c3cccc(Cl)c3)n2)ccc1O</smiles><smiles>COc1cc(/C=C/c2cc(/C=C/c3ccc(O)c(OC)c3)n(-c3ccc([N+](=O)[O-])cc3[N+](=O)[O-])n2)ccc1O</smiles><smiles>COc1cc(/C=C/c2cc(/C=C/c3ccc(O)c(OC)c3)n(-c3ccc(C#N)cc3)n2)ccc1O</smiles><smiles>COc1ccc(-n2nc(/C=C/c3ccc(O)c(OC)c3)cc2/C=C/c2ccc(O)c(OC)c2)cc1</smiles>

Fig 1. Series of curcumin pyrazole derivatives (3a-3e)

Table 1: In-vitro hypolipidemic activities $\left(\mathrm{IC}_{50}\right)$ of curcumin pyrazole derivatives (3a-3e) and curcumin

\begin{tabular}{|l|l|l|l|l|}
\hline Sl.no & Sample description & $\begin{array}{l}\text { Pancreatic lipase } \\
(\boldsymbol{\mu M})\end{array}$ & $\begin{array}{l}\text { Malic dehydrogenase } \\
(\boldsymbol{\mu M})\end{array}$ & $\begin{array}{l}\text { Glucose 6 phosphate } \\
\text { dehydrogenase }(\boldsymbol{\mu M})\end{array}$ \\
\hline 1 & Curcumin & 17.3913 & 23.42105 & 17.41379 \\
\hline 2 & 3a & 28.57143 & 18.54167 & 17.11864 \\
\hline 3 & 3b & 16 & 22.82051 & 14.02778 \\
\hline 4 & 3c & 33.33333 & 55.625 & 33.66667 \\
\hline 5 & 3d & 28.57143 & 44.5 & 21.04167 \\
\hline 6 & 3e & 26.66667 & 29.66667 & 18.7037 \\
\hline
\end{tabular}




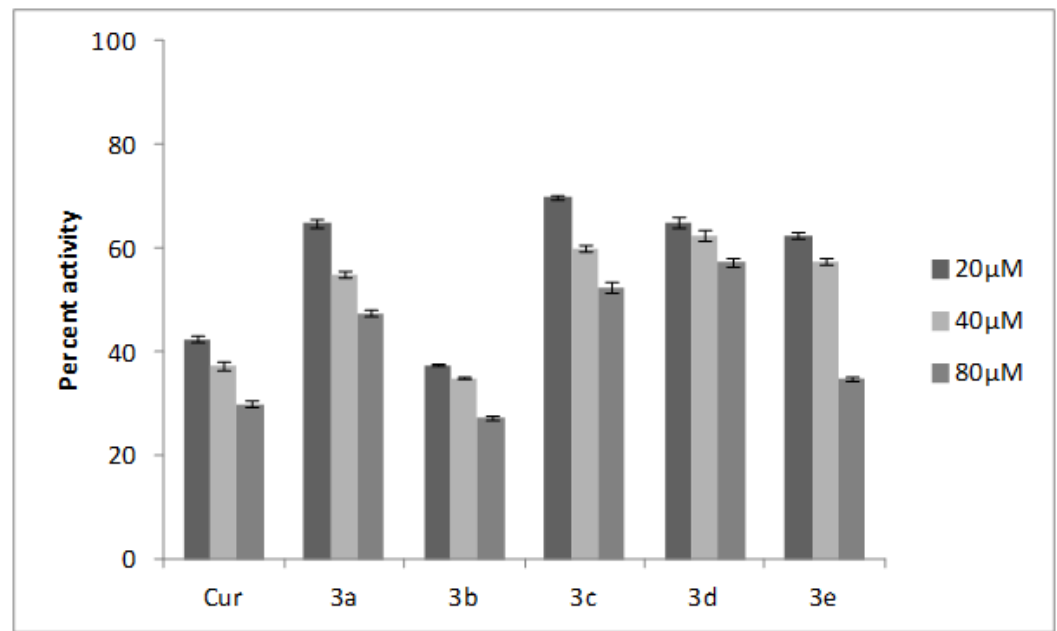

Values are expressed as mean \pm SEM $(n=3)$, SEM: Standard error mean.

Fig. 2: Pancreatic lipase enzyme inhibitory effects of curcumin and its pyrazole derivatives (3a-3e) at 20-80 $\mu \mathrm{M}$ concentrations showing percentage activity.

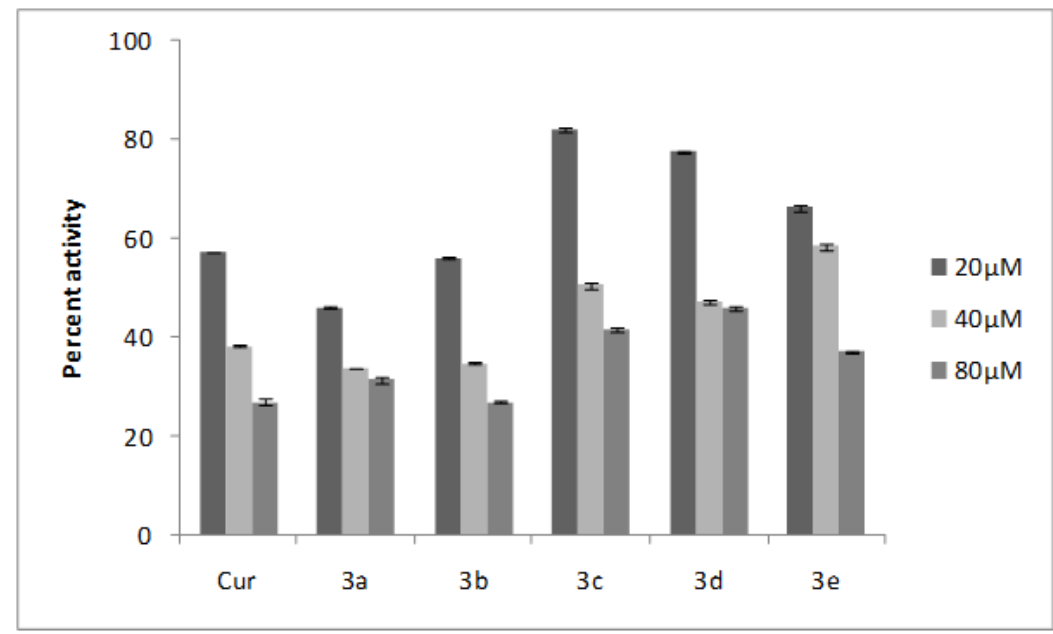

Values are expressed as mean \pm SEM $(n=3)$, SEM: Standard error mean.

Fig. 3: Malate dehydrogenase enzyme inhibitory effects of curcumin and its pyrazole derivatives (3a-3e) at 20$80 \mu \mathrm{M}$ concentrations showing percentage activity.

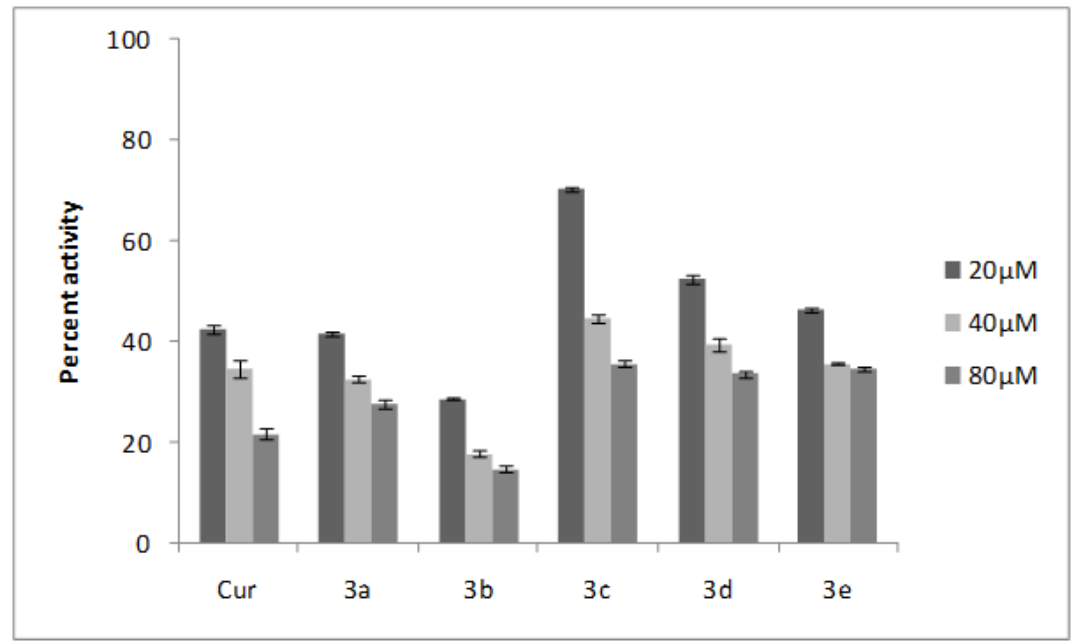

Values are expressed as mean \pm SEM $(\mathrm{n}=3)$, SEM: Standard error mean.

Fig. 4: Glucose 6 phosphate dehydrogenase enzyme inhibitory effects of curcumin and its pyrazole derivatives (3a-3e) at 20-80 $\mu \mathrm{M}$ concentrations showing percentage activity. 


\section{Conclusion}

Curcumin and its pyrazole derivatives (3a-3e) were studied to estimate the hypoglycemic effects of the compounds by the inhibition assays of the enzymes pancreatic lipase, glucose 6 phosphate dehydrogenase and malate dehydrogenase. All the compounds assessed exhibited hypolipidemic activity by attenuating the activity of the enzymes studied. Compound $3 a$ and $3 b$ was found to possess a prominent inhibitory activity which was comparable with the inhibitory activity of the curcumin. Compound $3 \mathrm{~b}$ was found to be more potent enzyme inhibitor. From our present investigations, compound $3 \mathrm{a}$ and compound $3 \mathrm{~b}$ could be concluded as promising hypolipidemic agents. However, further studies are needed to analyze structure activity interactions responsible for the overall hypolipidemic activities.

\section{References}

[1] L. Peter, P.M. Ridker, and A. Maseri, Inflammation and atherosclerosis, Circulation, 105(9), 2002, 1135-1143.

[2] S. Simvastatin Survival Study Group, "Randomised trial of cholesterol lowering in 4444 patients with coronary heart disease: the Scandinavian Simvastatin Survival Study (4S)." The Lancet 344(8934), 1994, 1383-1389.

[3] P. Bhushan, A.D.B. Vaidya, and M. Chorghade, Ayurveda and natural products drug discovery, Current Science-Bangalore, 86(6), 2004, 789-799.

[4] B.B. Aggarwal, C. Sundaram, N. Malani, and H. Ichikawa. "Curcumin: the Indian solid gold." In The molecular targets and therapeutic uses of curcumin in health and disease, Springer US, 2007, 1-75.

[5] B.B. Aggarwal, A. Kumar, A.C. Bharti, Anticancer potential of curcumin: Preclinical and clinical studies, Anticancer Research, 23, 2003, 363-398.

[6] P. Anand, A.B. Kunnumakkara, R.A. Newman, B.B. Aggarwal, Bioavailability of curcumin: Problems and promises, Mol Pharm 4, 2007, 807-818.

[7] K.M. Youssef, A. Magda, El-Sherbeny, Synthesis and antitumor activity of some curcumin analogs, Arch Pharm Chem Life Sci, 338, 2005, 181-189.

[8] H. Ohori, H. Yamakoshi, M. Tomizawa, M. Shibuya, Y. Kakudo, A. Takahashi, S. Takahashi, S. Kato, T. Suzuki, C. Ishioka, Y. Iwabuchi, H. Shibata, Synthesis and biological analysis of new curcumin analogues bearing an enhanced potential for the medicinal treatment of cancer, Mol Cancer Ther, 5, 2006, 2563-2571.

[9] R. Davis, U. Das, H. Mackay, T. Brown, S.L. Mooberry, J.R. Dimmock, M. Lee, H. Pati, Syntheses and cytotoxic properties of the curcumin analogs 2,6-Bis(benzylidene)-4-phenylcyclohexanones, Arch Pharm Chem Life Sci 341, 2008, 440-445.

[10] H. Chandru, A.C. Sharada, C.S. Ananda kumar, K.S. Rangappa, Antiangiogenic and growth inhibitory effects of synthetic novel 1, 5-diphenyl-1,4 pentadiene-3-one-3-yl-ethanone pyridine curcumin analogues on ehrlich ascites tumor in vivo, Medcinal Chemistry Research 17, 2008, 515-529.

[11] H. Chandru , A.C. Sharada , B.K. Bettadaiah, C.S. Ananda kumar, K.S. Rangappa, Sunila, K. Jayashree. (2007) In vivo growth inhibitory and anti-angiogenic effects of synthetic novel dienone cyclopropoxy curcumin analogs on mouse ehrlich ascites tumor. Bioorganic Med Chem 15:7696-7703.

[12] H.R. Puneeth, H. Ananda, K.S. Sharath Kumar, K.S. Rangappa, and A.C. Sharada, Synthesis and antiproliferative studies of curcumin pyrazole derivatives, Medicinal Chemistry Research, doi:10.1007/s00044-016-1628-5.

[13] H.R. Puneeth and A.C. Sharada, Antioxidant and hypoglycemic effects of curcumin pyrazole derivatives, International Journal of Pharmacy and Pharmaceutical Sciences, 7(4), 2015, 244-249.

[14] H.R. Puneeth and A.C. Sharada, Antidiabetic effects of a series of curcumin pyrazoles in-vitro, Asian Journal of Pharmaceutical and Clinical Research, 8(6), 2015, 146-149.

[15] J. Su, H. Wang, C. Ma, C. Liu, M.T. Rahman, C. Gao, R. Nie, Hypolipidemic mechanism of gypenosides via inhibition of pancreatic lipase and reduction in cholesterol micellar solubility, Europian of Food Research and Technology, 242, 2016, 305-312.

[16] Y. Xu, B.W. Osborne, R.C. Stanton, Diabetes causes inhibition of glucose-6-phosphate dehydrogenase via activation of PKA, which contributes to oxidative stress in kidney cortex, American Journal of Physiology. Renal Physiology, 289, 2005 , F1040-1047.

[17] A. Roobol, G.A.O. Alleyne, A study of stabilization of gluconeogenic activity in rat liver slices by calcium and manganese ions, Biochemistry Journal, 129, 1972, 231-239.

[18] C. Kong, L. Nimmo, T. Elatrozy, V. Anyaoku, C. Hughes, S. Robinson, W. Richmond, and R. S. Elkeles, Smoking is associated with increased hepatic lipase activity, insulin resistance, dyslipidaemia and early atherosclerosis in Type 2 diabetes, Atherosclerosis 156(2), 2001, 373-378.

[19] F. Martins, T.M. Noso, V.B. Porto, A. Curiel, A. Gambero, D.H. Bastos, M.L. Ribeiro, P.O. Carvalho, Mate tea inhibits in vitro pancreatic lipase activity and has hypolipidemic effect on high-fat diet-induced obese mice, Obesity, 18, 2010, $42-47$.

[20] J.P. Wynn, A.B.A. Hamidt, and C. Ratledge, The role of malic enzyme in the regulation of lipid accumulation in filamentous fungi, Microbiology 145, 1999, 1911-1917.

[21] R.F. Kletzien, P.K. Harris, and L.A. Foellmi, Glucose-6-phosphate dehydrogenase: a" housekeeping" enzyme subject to tissuespecific regulation by hormones, nutrients, and oxidant stress, The FASEB Journal 8(2), 1994, 174-181. 